\title{
Bioactivity of the latex from Parahancornia amapa (Apocynaceae) on the development of Rhodnius nasutus (Hemiptera, Reduviidae, Triatominae) under laboratory conditions
}

\author{
Marcio B. P. Lopes ${ }^{1,4}$, Paloma M. Mendonça ${ }^{1,3}$, Jacenir R. S. Mallet ${ }^{1}$, \\ Mário G. Carvalho² \& Margareth M. C. Queiroz ${ }^{1}$
}

\begin{abstract}
${ }^{1}$ Laboratório de Transmissores de Leishmanioses - Setor de Entomologia Médica e Forense/IOC, FIOCRUZ, Av. Brasil, 4365, 21045-900, Rio de Janeiro-RJ, Brasil.pinto@ioc.fiocruz.br

${ }^{2}$ Departamento de Química Orgânica - Universidade Federal Rural do Rio de Janeiro/UFRRJ.

${ }^{3}$ Programa de Pós-Graduação em Ciências Veterinárias - Universidade Federal Rural do Rio de Janeiro/UFRRJ.

${ }^{4}$ Programa de Pós-Graduação em Biologia Animal - Universidade Federal Rural do Rio de Janeiro/UFRRJ, Br 465, Km 7 Seropédica, 23890-000, Rio de Janeiro, RJ, Brasil.
\end{abstract}

\begin{abstract}
Bioactivity of the latex from Parahancornia amapa (Apocynaceae) on the development of Rhodnius nasutus (Hemiptera, Reduviidae, Triatominae) under laboratory conditions. The aim of this study was to verify the effects of the methanolic fraction of the latex from Parahancornia amapa (Apocynaceae) (PALAM) on individuals of the species Rhodnius nasutus Stål (Hemiptera, Triatominae). Many of the insects treated with the substance presented deformities and these may interfere in the feeding and possibly hinder the reproductive capacity. They also presented significant mortality during the molt when compared to the control group, noting a gradual increase in mortality. The treated insects also presented delayed nymphal development $\left(5^{\text {th }}\right.$ instar) and higher adult longevity.
\end{abstract}

KEY WORDS. Laboratory conditions; natural products; PALAM; triatomine; vector control.

Rhodnius nasutus Stål, 1859 (Reduviidae, Triatominae) is geographically restricted to the northeast region of Brazil (Galvão et al. 2003). This species could be considered of secondary importance in the transmission of Trypanosoma cruzi Chagas, 1909 (Alencar 1987). In studies conducted in Piauí, several authors have found that $R$. nasutus is a typical wild triatomine that colonizes natural ecotypes such as birds' nests and palm trees, mainly the babaçu (Orbignya marti) and carnaúba (Copernicia cerifera) and is less abundant in artificial ecotypes (Soares et al. 1995). According to Lima \& Sarquis (2007), the deforestation of carnaúba for raising cattle and agricultural development is diminishing the wild areas for this species, and thus this insect is being found in peri-urban environments. Therefore, changes in relation to the environment of this species have increased its vector potential as a possible transmitter of Chagas disease. Many cases of Chagas disease caused by $R$. nasutus have been described and this triatomine species has been found to be highly infected by T. cruzi (Lima et al. 2008). Thus to combat Chagas disease effectively it is essential to control the vectors (Rey 2008).

Biopesticides provide an alternative to synthetic pesticides because they have low impact on the environment, low toxicity to humans, and low costs as well as other advantages (Liu et al. 2000). Traditionally plants from the family Apocynaceae are widely used as medicinal plants and as insecticides. Parahancornia amapa (Huber) Ducke (Apocynaceae) is a native tree from the State of Amapá in the Amazon region. Like other species of the family Apocynaceae, this plant produces a white latex, commonly known as "leite do Amapá", which is mixed with honey or drinks for human consumption (Van den Berg 1982). The phytochemical study of $P$. amapa latex revealed the presence of acyl-lupeol esters besides a large amount of carbohydrate and phenylethanoids detected as principal compounds in the methanol fraction such as the methylmyoinositol and the glycoside known as cornoside (Carvalho et al. 2008).

Based on these data, we decided to evaluate the bioactivity of a methanolic fraction of $P$. amapa latex on the $5^{\text {th }}$ instar nymphs of $R$. nasutus. The third generation of a stock colony of this insect established at the Laboratório de Transmissores de Leishmanioses, Setor de Entomologia Médica e Forense, Instituto Oswaldo Cruz, Fundação Oswaldo Cruz, Rio de Janeiro, RJ was used for this study. The insects were maintained under laboratory conditions $\left(24-30{ }^{\circ} \mathrm{C} ; 60-85 \% \mathrm{RH}\right)$. The photoperiod was not controlled. 
The plant material used was collected from one specimen identified by the botanist Benedito Vitor Rabello in the State of Amapá, Brazil. The voucher specimen $\left(n^{\circ} 07231\right)$ is deposited at the Herbário Amapaense (HAMAB) of the Divisão de Botânica do Museu Angelo Moreira da Costa Lima, Instituto de Estudos e Pesquisas do Amapá (IEPA), Macapá-AP, Brazil.

The dried latex $(100.0 \mathrm{~g})$ was extracted by maceration three times with hexane, dichloromethane and with methanol at room temperature and lyophilized to afford the residues PALAH (methanolic fraction of hexane partition) (37.5 g), PALAD (methanolic fraction of dichloromethane partition) (30.0 g) and PALAM (methanolic fraction of methanol partition) (25.0 $\mathrm{g})$. The residue PALAM (15.0 g) was dissolved in methanol and submitted to Sephadex LH-20 column chromatography, eluted with methanol. The ${ }^{1} \mathrm{H}$ and ${ }^{13} \mathrm{C}$ NMR spectra showed signals of glycopyranoside (1) together with signals compatible with other phenylethanoid derivatives such as $1 \mathrm{~b}, 2,2 \mathrm{a}$, and 3. The GC-MS analysis afforded a chromatogram whose analysis of each corresponding mass spectrum considering the main peaks led us to identify $1 \mathrm{~b}$ as [4-hydroxy-4-(2hydroxyethyl)-2,5-cyclohexadien-1-one, certainly yielded from 1]; 2 as [ethanol-2-(ciclohexyl-1-hydroxy-5-methoxy-2en-4-one); and 3 as [4-hydroxyphenylethanol (tyrosol). The absence of a corresponding peak for 2 a suggested it was a derivative from 2. Quinol glucoside 1, known as cornoside (Jiménez \& Riguera 1994), was identified by IR, NMR spectra, including 2D-NMR experiments, besides mass spectrum and comparison with literature data (Khan et al. 1992). 1 (50.0 $\mathrm{mg})$, which was treated with acetic anhydride and pyridine $(1: 1)$ at room temperature overnight, following usual work-up and filtration through a silica gel column, yielded the tetraacetyl derivative $1 \mathrm{a}$ (m.p. $219-220^{\circ} \mathrm{C}, 40.0 \mathrm{mg}$ ). The analysis of $1 \mathrm{H}$ and 13C NMR spectra of a solid material $(300.00 \mathrm{mg})$, revealed the presence of the carbohydrate (4). $30.0 \mathrm{mg}$ of 4 was acetylated in the same way as 1 to obtain the derivative $4 \mathrm{a}$ (Fig. 1) (Carvalho et al. 2008).

The soluble methanol fraction, named PALAM, was applied topically on the abdomen in the concentrations of 2, 3 and 4\% (based on Mendonça et al. 2011), diluted in distilled water. A total of 360 individuals were separated in test and control groups (divided in three replicates). The in vivo feeding was done weekly on mice of the species Mus musculus L. During the experiment, the observations were made every other day.

The parameters analyzed were: number of ecdyses, duration and viability of the $5^{\text {th }}$ instar, as well as viability and longevity of the adults. Morphological alterations of the adults from the test groups were analyzed using scanning electron microscopy (SEM), as described by Santos-Mallet et al. (2005). The statistical program used to analyze the data was GraphPad InStat. The results were analyzed by ANOVA and the means were compared with the Tukey-Kramer test (Sokal \& Rohlf 1979).

The longevity of adults of $R$. nasutus from the treated groups did not differ significantly from those of the control

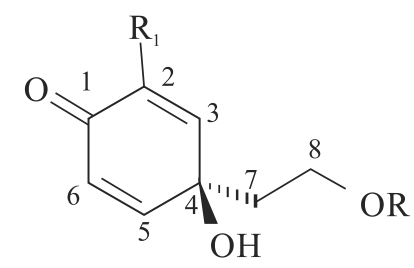

1: $\mathrm{R}=$ gluc, $\mathrm{R}_{1}=\mathrm{H}$

1a: $\mathrm{R}_{1}=\mathrm{H}, \mathrm{R}=$ gluc $-(\mathrm{Ac})_{4}$

1b: $\mathrm{R}=\mathrm{R}_{1}=\mathrm{H}$

2: $\mathrm{R}=\mathrm{H}, \mathrm{R}_{1}=\mathrm{OCH}_{3}, 2,3$-dihydro

OR<smiles>[R]c1cc(CCO)ccc1O</smiles>

2a: $\mathrm{R}=\mathrm{OCH}_{3}$

3: $\mathrm{R}=\mathrm{H}$

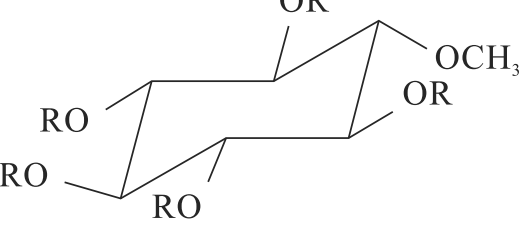

4: $\mathrm{R}=\mathrm{H}$

4a: $\mathrm{R}=\mathrm{Ac}$

Fig. 1. Chemical constituents of the latex from Parahancornia amapa.

group (29.61 \pm 17.71 days). However, there was significant difference among the insects of the treated groups (Table I). Rocha et al. (1997) observed a prolongation of the longevity of Rhodnius pictipes Stål, 1872 fed on mice when compared to the use of silica membranes. The treatment caused a significant elongation of the $5^{\text {th }}$ instar nymph period when compared to the control group (22.4 \pm 10.1 days) (Table I). On the other hand, no difference was observed among the treatments (Table I). Arévalo et al. (2007) reported duration of 29.7 days for the $5^{\text {th }}$ instar of $R$. prolixus reared on chicken. According to Carcavallo et al. (2000), R. nasutus belongs to the same complex as $R$. prolixus and the biological behavior of these species is very similar.

Table I. Duration of development ( $5^{\text {th }}$ instar/adult) and longevity (days) of adults of Rhodnius nasutus (Hemiptera, Triatominae), treated with different concentrations of methanolic fraction of the latex of Parahancornia amapa (Apocynaceae), under methanolic fraction of
laboratory conditions.

\begin{tabular}{cccccc}
\hline \multirow{2}{*}{$\begin{array}{c}\text { Groups } \\
\text { (Treatments) }\end{array}$} & \multicolumn{2}{c}{$\begin{array}{c}\text { Development of } 5^{\text {th }} \text { instar to adult } \\
\text { (days) }\end{array}$} & & \multicolumn{2}{c}{$\begin{array}{c}\text { Longevity } \\
\text { (days) }\end{array}$} \\
\cline { 2 - 3 } \cline { 5 - 6 } \cline { 5 - 6 } & $\mathrm{m} \pm \mathrm{SD}$ & I.V. & & $\mathrm{m} \pm \mathrm{SD}$ & I.V. \\
\hline Control & $22.4 \pm 10.1 \mathrm{a}$ & $7-51$ & & $29.61 \pm 17.71 \mathrm{a}$ & $11-79$ \\
$2 \%$ & $29.2 \pm 11.4 \mathrm{~b}$ & $7-74$ & & $23.04 \pm 9.27 \mathrm{ab}$ & $5-49$ \\
$3 \%$ & $29.5 \pm 13.0 \mathrm{~b}$ & $7-63$ & & $29.64 \pm 16.69 \mathrm{ab}$ & $3-98$ \\
$4 \%$ & $33.1 \pm 16.8 \mathrm{~b}$ & $3-77$ & & $37.43 \pm 19.40 \mathrm{ac}$ & $12-81$ \\
\hline
\end{tabular}

$\mathrm{m}$, the average, SD standard deviation and I.V., interval variation (amplitude). Different letters indicate significant differences.

Morphological alterations were observed only for the treated groups (Figs. 2 and 3). There was a significant difference among the three tested concentrations, but only for legs deformities (Table II). Concurrent deformity of the wings and legs was not significantly different and represented 14.6 and $13.9 \%$ for the 3 and $4 \%$ treated groups, respectively (Table II). There is no report of any morphological alterations of $R$. nasutus in the literature. However, some authors have 


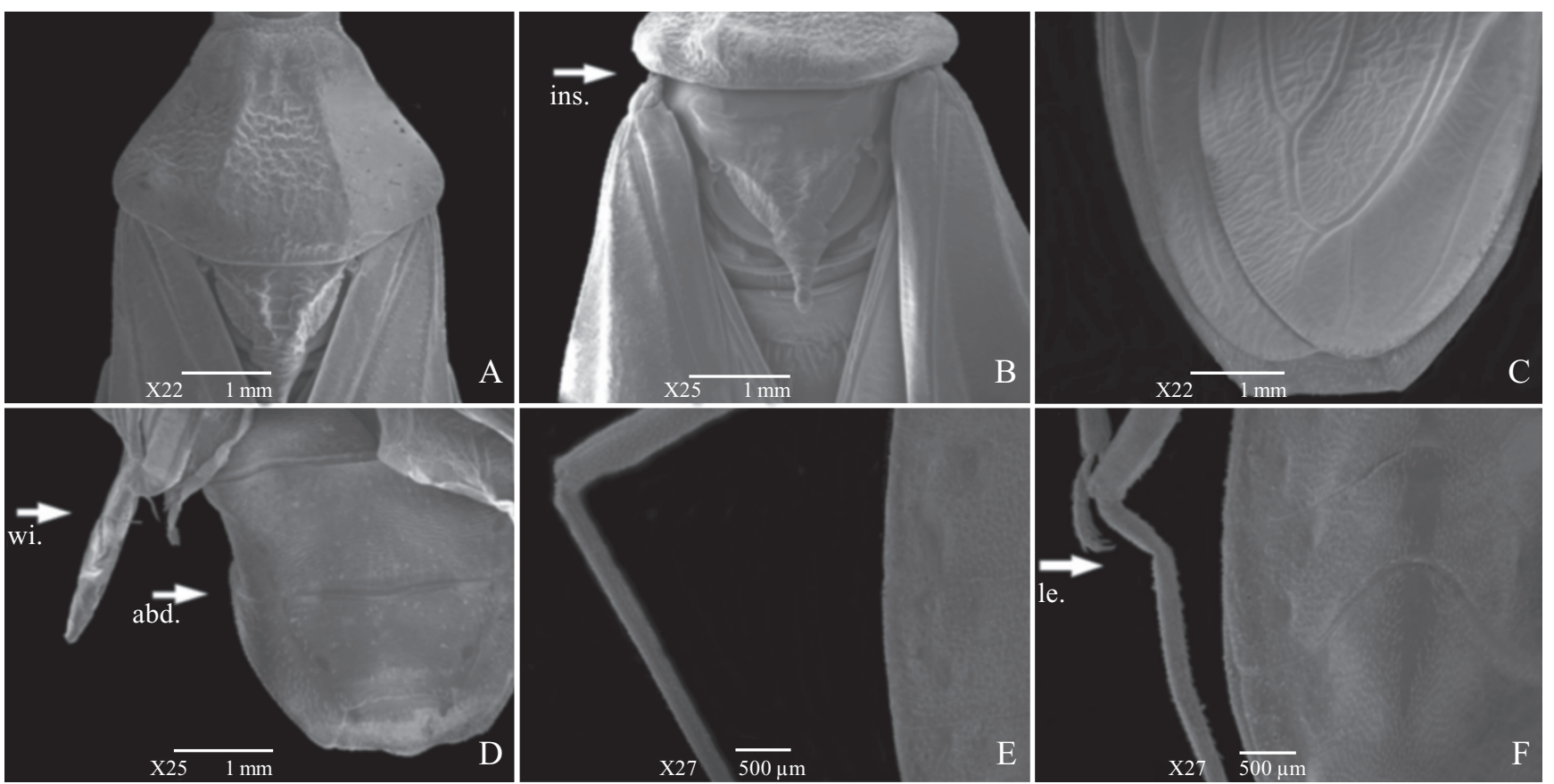

Fig. 2. Scanning eletron micrographs of adult Rhodnius nasutus. A - Dorsal view of the thorax of adult, control group and without deformities; B Dorsal view of the thorax of adult group treated with different concentrations of methanolic fraction of the latex of Parahancornia amapa, with deformity in the insertion of the wings (ins.); $\mathrm{C}$ - View of the posterior region abdomen control group, without deformities; D - Posterior view of adult treated group with P. amapa, with deformities of the wings (wi.) and abdomen (abd.); E - View of the legs of adult control group, without deformities; $\mathrm{F}$ - View of the legs of adult treated group with P. amapa, with deformities of the legs (le.).

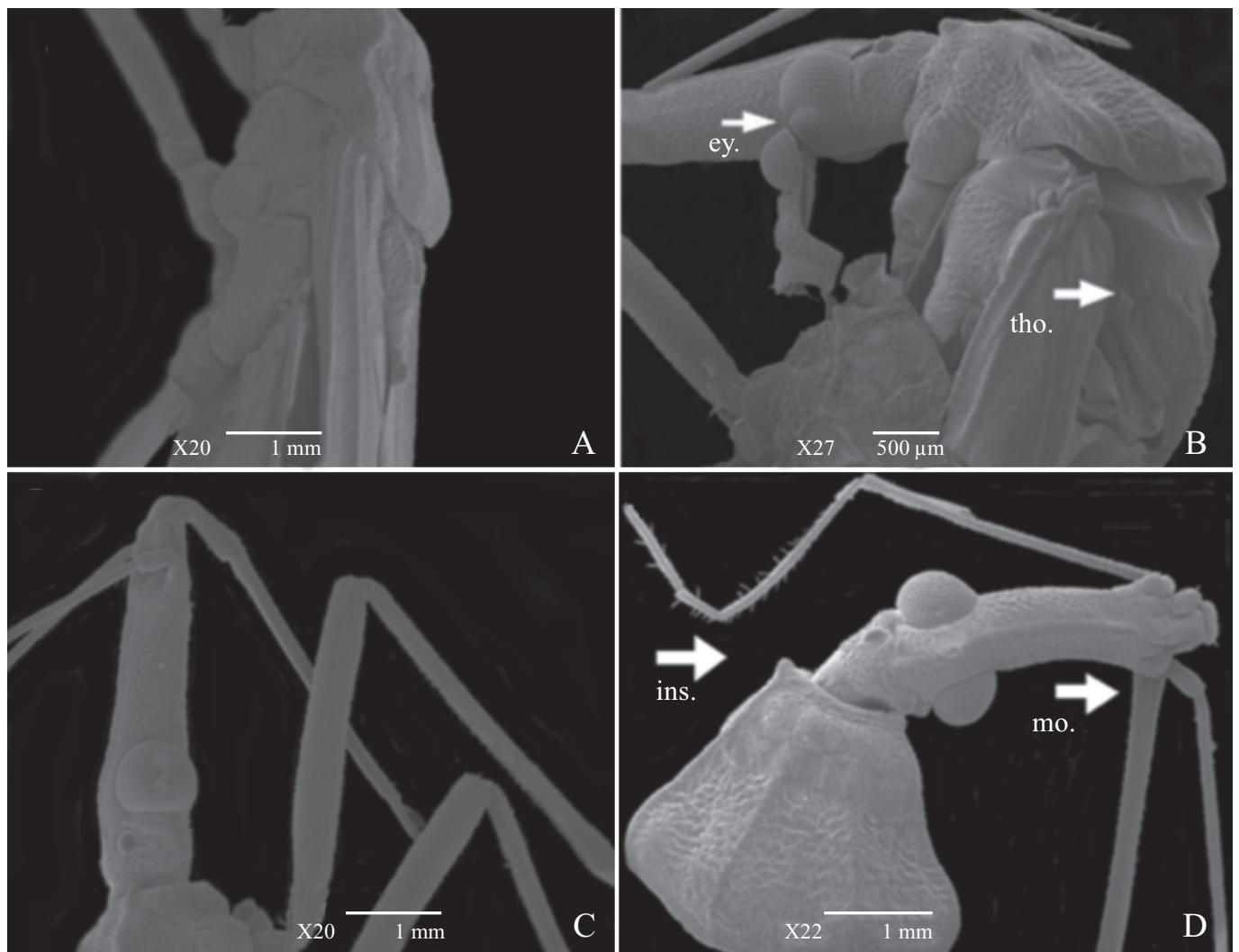

Fig. 3. Scanning eletron micrographs of adult Rhodnius nasutus. A - Lateral view of the adult control group, without deformities; B - Lateral view of the adult treated group with methanolic fraction of the latex of Parahancornia amapa, with deformities in the eyes (ey.) and in the thorax (tho.); $\mathrm{C}-$ Lateral view of the adult control group, without deformities; D - Dorsal view of the adult treated group with P. amapa, with deformities on mouthparts (mo.) and insertion of the head (ins.). 
Table II. Simultaneous deformities in adults of Rhodnius nasutus (\%), treated with different concentrations of methanolic fraction of the latex of Parahancornia amapa.

\begin{tabular}{ccccccccc}
\hline Group (Treatments) & Head & Legs & Wings & Abdomen & Head/Legs & Wings/Legs & Legs/Mouthparts & Wings/Head/Legs \\
\hline Control & 0 & 0 & 0 & 0 & 0 & 0 & 0 \\
$2 \%$ & 4.2 & 75.0 & 4.2 & 0 & 4.2 & 4.2 & 14.6 & 0 \\
$3 \%$ & 0 & 70.8 & 2.1 & 0 & 4.6 & 13.9 & 0 \\
$4 \%$ & 2.3 & 62.9 & 4.6 & 2.3 & 8.3 & 6.9 \\
\hline
\end{tabular}

Table III. Mortality of nymphs of $5^{\text {th }}$ instar, during ecdysis, percentage (\%) of dead adults and with morphological alteration (\%) of Rhodnius nasutus, treated with different concentrations of methanolic fraction of the latex of Parahancornia amapa, under laboratory conditions.

\begin{tabular}{|c|c|c|c|c|c|c|}
\hline \multirow{2}{*}{$\begin{array}{c}\text { Group } \\
\text { (Treatments) }\end{array}$} & \multirow{2}{*}{$\begin{array}{c}\text { Nymph mortality } \\
\% \\
\end{array}$} & \multirow{2}{*}{$\begin{array}{c}\text { Mortality during ecdysis } \\
\%\end{array}$} & \multicolumn{2}{|c|}{ Adult mortality without deformity } & \multicolumn{2}{|c|}{ Adult mortality deformity } \\
\hline & & & Total number & $\%$ & Total number & $\%$ \\
\hline Control & 11.1 & 14.4 & 67 & 100.0 & 0 & 0 \\
\hline $2 \%$ & 18.8 & 23.3 & 25 & 51.1 & 24 & 48.9 \\
\hline $3 \%$ & 14.4 & 26.6 & 8 & 14.3 & 48 & 85.7 \\
\hline $4 \%$ & 8.9 & 58.8 & 10 & 21.9 & 43 & 78.1 \\
\hline
\end{tabular}

reported that natural extracts can cause morphological alterations in insect species (Fernandes et al. 2012; Cabral et al. 2000). These morphological alterations found using the scanning electron microscopy can hinder the locomotion of the insect and decrease the dispersion activity of the triatomine. The dispersion of the insect is an important factor for epidemiology (Brenner et al. 2000).

No significant difference was observed for the mortality of the nymphs. The mortality of the nymphs was higher at 2 and $3 \%$. However, the mortality during the ecdysis was significantly different when comparing the treated groups with the control, demonstrating a summation total of nymph mortality/mortality during the ecdysis of $42.1,41$ and $67.7 \%$, respectively 2, 3 and $4 \%$ (Table III).

In conclusion, the results showed that the triatomine $R$. nasutus suffered morphological alterations and the development of the insect from $5^{\text {th }}$ instar nymphs to adult was affected, as well as the longevity of adults and the mortality. We can suggest that these results are due to the activity of a methylmyoinositol and the glycoside known as cornoside, which were detected as the principal compounds in the methanolic fraction obtained from the latex extraction "PALAM" (Carvalho et al. 2008).

\section{ACKNOWLEDGMENTS}

The authors are grateful for the financial support received from the Instituto Oswaldo Cruz (IOC/FIOCRUZ), Conselho Nacional de Desenvolvimento Científico e Tecnológico (CNPq), Coordenação de Aperfeiçoamento de Pessoal de Nivel Superior (CAPES) and Fundação de Amparo à Pesquisa do Estado do Rio de Janeiro (FAPERJ).

\section{REFERENCES}

Alencar, J.E. 1987. História natural da doença de Chagas no Estado do Ceará. Fortaleza, Universidade Federal do Ceará, 341 p.

Arévalo, A., Carranza, J.C., Guhl, F., Clavijo, J.A. \& Vallejo, G.A. 2007. Comparación del ciclo de vida de Rhodnius colombiensis Moreno,
Jurberg \& Galvão, 1999 y Rhodnius prolixus Stål, 1872 (Hemiptera, Reduviidae, Triatominae) en condiciones de laboratorio. Biomédica 27: 119-29.

Brenner, Z., Andrade, Z.A. \& Neto, M.B. 2000. Trypanosoma cruzi e Doença de Chagas. 2nd ed. Rio de Janeiro, Ed. Guanabara Koogan, 431 p.

Cabral, M.M.O., Kollien, A.H., Kleffmann, T., Azambuja, P., Gottlieb, O.R., Garcia, E.S. \& Schaub, G.A. 2000. Rhodnius prolixus: Effects of the neolignan burchellin on in vivo and in vitro diuresis. Parasitology Research 86: 710-716.

Carvalho, M.G., Albuquerque, L.A., Alves, C.C.F. \& Cascon, V. 2008. Cornoside and other constituents from the latex of Parahancornia amapa (Hub.) Ducke (Apocyncaceae) a medicinal plant in Northern Brazil. Revista Brasileira de Farmacognosia 18: 667-669.

Carcavallo, R.U., Jurberg, J., Lent, H., Noireau, F. \& Galvão, C. 2000. Phylogeny of the Triatominae (Hemiptera, Reduviidae). Proposals for taxonomic arrangements. Entomología y Vectores 7: 1-86.

Fernandes, C.P., Xavier, A., Pacheco, J.P.F., Santos, M.G., Mexas, R., Ratcliffe, N.A., Gonzalez, M.S., Mello, C.B., Rocha, L. \& Feder, D. 2012. Laboratory evaluation of the effects of Manilkara subsericea (Mart.) Dubard extracts and triterpenes on the development of Dysdercus peruvianus and Oncopeltus fasciatus. Pest Management Science 69: 292-301.

Galvão, C., Carcavallo, R., Rocha, D.S. \& Jurberg, J. 2003. A checklist of the current valid species of the subfamily Triatominae Jeannel, 1919 (Hemiptera, Reduviidae) and their geographical distribution, with nomenclatural and taxonomic notes. Zootaxa 202: 1-36.

Jiménez, C. \& Riguera, R. 1994. Phenylethanoid glycosides in plants: Structure and biological activity. Natural Product Reports 11: 591-606.

Khan, A.I., Erdelmeier, C.A.J., Sticher, O. \& Rali, T. 1992. New phenolic glucosides from the leaves of Eurya tigang. Journal of Natural Products 55: 1270-1274.

Lima, M.M., Coutinho, C.F.S., Gomes, T.F., Oliveira, T.G., Duarte, R., Borges-Pereira, J., Bóia, M.N. \& Sarquis, O. 2008. Risk presented by Copernicia prunifera palm trees in the Rhodnius nasutus distribution in a Chagas disease-endemic area of the Brazilian northeast. The American Journal of Tropical Medicine and Hygiene 79: 750-754.

Lima, M.M. \& Sarquis, O. 2007. Is Rhodnius nasutus (Hemiptera; Reduviidae) changing its habitat as a consequence of human activity? Parasitology Research 102: 797-800.

Liu, S.Q., Shi, J.J., Cao, H., Jia, F.B., Liu, X.Q. \& Shi, G.L. 2000. Survey of pesticidal component in plant, pp. 1098-1104. In: Dianmo, L. (Ed.). Entomology in China in 21st Century, Proceedings of Conference of Chinese Entomological Society. Beijing, Science \& Technique Press.

Mendonça, P.M., Lima, M.G., Albuquerque, L.R.M., Carvalho, M.G. \& Queiroz, M.M.C. 2011. Effects of latex from "Amapazeiro" Parahancornia amapa (Apocynaceae) on blowfly Chrysomya 
megacephala (Diptera: Calliphoridae) post-embryonic development. Veterinary Parasitology 178: 379-382.

Rey, L. 2008. Parasitologia. 4th Ed. Rio de Janeiro, Ed. Guanabara Koogan, 930p.

Rocha, D.S., Fonseca, A.H., Costa, F.A., Juberg, J. \& Galvão, C. 1997. Desenvolvimento de Rhodnius pictipes Stål, 1872, alimentado através de membrana de silicone e em camundongos (Hemiptera: Triatominae). Memórias do Instituto Oswaldo Cruz 92: 553-558.

Santos-Mallet, J.R., Junqueira, A.C.V., Moreira, C.J.C., Andrade, Z., Coura, J.R. \& Gonçalvez, T.C.M. 2005. Morphobiological aspects of Rhodnius brethesi Matta, 1919 (Hemiptera: Reduviidae) from the Upper and
Middle Negro River, Amazon region of Brazil. I - Scanning electron microscopy. Memórias Instituto Oswaldo Cruz 100: 915-923.

Soares, M.J.S., Santos Filho, P.N., Bento, D.N.C. 1995. Estudo do ciclo evolutivo do Rhodnius nasutus Stal, 1859, em laboratório. Revista da Sociedade Brasileira de Medicina Tropical 28: 113-116.Sokal, R.R. \& Rohlf, F.J. 1979. Biometriìa: principios y métodos estadísticos en la investigacioìn biológica. 1st Ed. Madrid, H. Blume Ediciones, $832 \mathrm{p}$.

Van den Berg M.E. 1982. Plantas Medicinais na Amazônia - Contribuição ao Seu Conhecimento Sistemático. Belém, Museu Paraense Emilio Goeldi, 223 p. 